\title{
Elevation of Basal Intracellular Calcium as a Central Element in the Activation of Brain Macrophages (Microglia): Suppression of Receptor-Evoked Calcium Signaling and Control of Release Function
}

\author{
Anja Hoffmann, Oliver Kann, Carsten Ohlemeyer, Uwe-Karsten Hanisch, and Helmut Kettenmann \\ Department of Cellular Neurosciences, Max Delbrück Center for Molecular Medicine, D-13092 Berlin, Germany
}

Microglia- brain macrophages are immune-competent cells of the CNS and respond to pathologic events. Using bacterial lipopolysaccharide (LPS) as a tool to activate cultured mouse microglia, we studied alterations in the intracellular calcium concentration $\left(\left[\mathrm{Ca}^{2+}\right]_{\mathrm{i}}\right)$ and in the receptor-evoked generation of transient calcium signals. LPS treatment led to a chronic elevation of basal $\left[\mathrm{Ca}^{2+}\right]_{\mathrm{i}}$ along with a suppression of evoked calcium signaling, as indicated by reduced $\left[\mathrm{Ca}^{2+}\right]_{\mathrm{i}}$ transients during stimulation with UTP and complement factor $5 \mathrm{a}$. Presence of the calcium chelator BAPTA prevented the activation-associated changes in $\left[\mathrm{Ca}^{2+}\right]_{\mathrm{i}}$ and restored much of the signaling efficacy. We also evaluated downstream consequences of a basal $\left[\mathrm{Ca}^{2+}\right]_{\mathrm{i}}$ lifting during microglial activation and found BAPTA to strongly attenuate the LPS-induced release of nitric oxide (NO) and certain cytokines and chemokines. Furthermore, microglial treatment with ionomycin, an ionophore elevating basal $\left[\mathrm{Ca}^{2+}\right]_{\mathrm{i}}$, mimicked the activation-induced calcium signal suppression but failed to induce release activity on its own. Our findings suggest that chronic elevation of basal $\left[\mathrm{Ca}^{2+}\right]_{\mathrm{i}}$ attenuates receptor-triggered calcium signaling. Moreover, increased $\left[\mathrm{Ca}^{2+}\right]_{\mathrm{i}}$ is required, but by itself is not sufficient, for release of NO and certain cytokines and chemokines. Elevation of basal $\left[\mathrm{Ca}^{2+}\right]_{\mathrm{i}}$ could thus prove a central element in the regulation of executive functions in activated microglia.

Key words: BAPTA; C5a; CD88; fura-2; ionomycin; UTP

\section{Introduction}

Microglia constitutes the macrophage equivalent of the CNS. In response to pathological events, the normally "resting" microglia gradually transform into motile, secretory active and potentially cytotoxic phagocytes (Kreutzberg, 1996; Schwaiger et al., 1998; Raivich et al., 1999a; Streit et al., 2000; Hanisch, 2001). Activated microglial cells then participate in mechanisms of innate and immune defense, tissue repair, and neuroprotection. However, experimental and clinical evidence also supports the notion that excessive microglial activation exacerbates destructive cascades.

Microglia express a variety of receptors that allow for a monitoring of the surrounding tissue (Nörenberg et al., 1994; Kreutzberg, 1996; Streit et al., 2000). Receptors for neurotransmitters and cotransmitters could be important for sensing neuronal activity, and microglia express functional glutamatergic, adrenergic, and purinoreceptors (Noda et al., 2000; Prinz et al., 2001). Abnormal receptor signaling (excessive intensities or dis-

Received Nov. 19, 2002; revised Jan. 29, 2003; accepted Feb. 27, 2003.

This work was supported by German Research Foundation Grants H02205/1 (A.H.), GRK 238 (0.K.), and SFB 507 (U.-K.H. and H.K.). We thank Gerda Müller, Silke Fleischhauer, Jörg Scheffel, and Madlen Driesner for excellent technical assistance.

A.H. and O.K. contributed equally to this work.

U.-K.H. and H.K. contributed equally to this work.

Correspondence should be addressed to Dr. Helmut Kettenmann, Max Delbrück Center for Molecular Medicine, Cellular Neurosciences, Robert-Rössle-Strasse 10, D-13092 Berlin, Germany. E-mail: hketten@mdc-berlin.de.

0. Kann's present address: Institute for Physiology, Humboldt University Berlin, Tucholskystrasse 2, D-10117 Berlin, Germany.

U.-K. Hanisch's present address: University of Applied Sciences Lausitz, Grossenhainer Strasse 57, D-01968 Senftenberg, Germany.

Copyright $\odot 2003$ Society for Neuroscience $\quad 0270-6474 / 03 / 234410-10 \$ 15.00 / 0$ ruption) could indicate homeostatic disturbance and trigger microglial responses. Microglia also express receptors for immune system mediators, namely for cytokines, chemokines, and complement (Möller et al., 1997; Harrison et al., 1998; Raivich et al., 1999b; Hanisch, 2001). Some of these factors may play physiological roles in the developing and healthy adult CNS. Others appear only under pathological conditions (Hopkins and Rothwell, 1995; Merrill and Benveniste, 1996; Hanisch, 2002; Häusler et al., 2002). Some receptors are upregulated during activation (Raivich et al., 1998). In contrast, activated microglia can also exhibit decreased responsiveness to receptor stimulation. As demonstrated recently, purinergic ligands evoked only attenuated reactions in cells that were activated with bacterial lipopolysaccharide (LPS) (Möller et al., 2000b). LPS triggers activation of macrophage-like cells and is used as a tool to mimic Gramnegative infection (abd-el-Basset and Fedoroff, 1995; Ulevitch and Tobias, 1995).

The intracellular calcium concentration $\left(\left[\mathrm{Ca}^{2+}\right]_{\mathrm{i}}\right)$ influences multiple cellular functions, including enzyme or release activities. Transient $\left[\mathrm{Ca}^{2+}\right]_{\mathrm{i}}$ increases serve the intracellular signaling of numerous plasma membrane receptors (Verkhratsky et al., 1998). Also in microglia, several receptors are linked to the calcium signaling machinery, e.g., those for "classical" neurotransmitters as well as those for immune system mediators (Kreutzberg, 1996; Nolte et al., 1996; Verkhratsky and Kettenmann, 1996; Möller et al., 1997; Boddeke et al., 1999; Hide et al., 2000; Möller et al., 2000a,b). Calcium may serve as an integrator of their cytosolic consequences to control microglial behavior under resting and activated conditions. 
Amplitude and kinetics of a calcium signal are determined by features of the ligand-receptor system and its cytosolic effector cascade. This includes $\mathrm{Ca}^{2+}$ release from inositol-1,4,5-triphopshate or ryanodine-sensitive intracellular $\mathrm{Ca}^{2+}$ stores, the status of calcium release-activated calcium channels, and the efficacy of the calcium-buffering system (Verkhratsky et al., 1998).

However, the calcium signal might also be influenced by the basal $\left[\mathrm{Ca}^{2+}\right]_{\mathrm{i}}$. Its level is maintained by the activity of calcium pumps and the rate of constitutive $\mathrm{Ca}^{2+}$ influx. We demonstrate that LPS activation of mouse microglia in vitro leads to elevated basal $\left[\mathrm{Ca}^{2+}\right]_{\mathrm{i}}$ along with attenuated $\mathrm{Ca}^{2+}$ signaling in response to extracellular stimulation of selected purinoreceptors and complement receptors. Furthermore, we present evidence that the rise in $\left[\mathrm{Ca}^{2+}\right]_{\mathrm{i}}$ is necessary to allow for characteristic features of microglial activation, such as release of nitric oxide (NO) and certain cytokines and chemokines. We hypothesize that an activation-related lasting increase in the basal $\left[\mathrm{Ca}^{2+}\right]_{\mathrm{i}}$ level critically determines receptor signaling efficacy and executive behavior of macrophage-like cells.

\section{Materials and Methods}

Microglial cultures. Cells were prepared from newborn NMRI mice (Tierzucht Schönwalde, Schönwalde, Germany) and cultured in DMEM-10\% fetal calf serum as described previously (Prinz et al., 1999). Cells were plated on glass coverslips $\left(10^{5}\right.$ cells $/ \mathrm{cm}^{2}$, imaging and staining experiments $)$ or in Petri dishes $\left(2 \times 10^{6}\right.$ cells, biochemical analyses $)$. Ninetyeight percent of the cells were microglia, as revealed by staining (Prinz et al., 1999). Cells were activated with LPS (100 ng/ml, Escherichia coli K-235, 24 hr; Sigma, Deisenhofen, Germany). Incubations with BAPTA AM (10-50 $\mu \mathrm{M})$ (Sigma) and ionomycin (1-1000 nм) (Sigma) were performed for the same time period.

Calcium measurements. Experiments were performed in HEPES buffer (in mM: $150 \mathrm{NaCl}, 5.4 \mathrm{KCl}, 2 \mathrm{CaCl}_{2}, 1 \mathrm{MgCl}_{2}, 10 \mathrm{HEPES} / \mathrm{NaOH}$, and 10 glucose, $\mathrm{pH} 7.35)$ at room temperature. $\left[\mathrm{Ca}^{2+}\right]_{\mathrm{i}}$ was monitored using the calcium-sensitive fluorescent indicator fura-2 AM. Cells were loaded with fura-2 AM ( $5 \mu \mathrm{M}$; stock solution in DMSO; Molecular Probes, Eugene, OR) by incubation in bathing solution (30 min). For fura- 2 excitation, cells were illuminated with two alternating wavelengths, $340 \pm 5$ and $380 \pm 5 \mathrm{~nm}$. Excitation was performed by using a monochromator (Polychrome IV; T.I.L.L. Photonics, Martinsried, Germany). The emitted light was collected at $530 \pm 10 \mathrm{~nm}$ by the long-term exposure CCD camera QuantiCam Long Exposure VGA-b/w (Phase, Luebeck, Germany) coupled to a Zeiss (Oberkochen, Germany) Axioskop equipped with a $20 \times$ water immersion Zeiss objective (numerical aperture of 0.5 ). The monochromator and CCD camera were controlled by Axon Imaging Workbench 2.2 software (Axon Instruments, Union City, CA), being also used for image processing. Data analysis was performed using standard personal computer software. The $\left[\mathrm{Ca}^{2+}\right]_{\mathrm{i}}$ was calculated from the ratio (R) of fluorescence recorded at 340 and $380 \mathrm{~nm}$ excitation wavelengths. Calibrations (conversion of R 340/380 values into molar calcium concentrations) were performed as described previously (Grynkiewicz et al., 1985).

Cells were superfused with HEPES buffer, and images were taken every $3 \mathrm{sec}$. Basal $\left[\mathrm{Ca}^{2+}\right]_{\mathrm{i}}$ was determined from the initial 10 images of each cell recording. For eliciting $\left[\mathrm{Ca}^{2+}\right]_{\mathrm{i}}$ transients, the superfusion medium was switched for $30 \mathrm{sec}$ to a solution of UTP, recombinant human complement factor $5 \mathrm{a}$ (C5a), or ATP (as survival control after measurements) (100 $\mu \mathrm{M}, 2 \mathrm{nM}$, and $100 \mu \mathrm{M}$ in HEPES buffer, respectively; Sigma). A $\left[\mathrm{Ca}^{2+}\right]_{\mathrm{i}}$ signal was defined as an increase in R 340/380 with clear time correlation to the agonist application. Amplitudes $(\Delta \mathrm{R})$ were calculated as difference between R 340/380 basal and peak values.

CD88 immunocytochemistry. Cells were fixed (4\% paraformaldehyde in PBS, $20 \mathrm{~mm} \mathrm{Na}_{2} \mathrm{HPO}_{4} / \mathrm{NaH}_{2} \mathrm{PO}_{4}$, $\mathrm{pH} 7.4$, and $140 \mathrm{~mm} \mathrm{NaCl}, 15 \mathrm{~min}$ ) and incubated in block solution [PBS, 2\% bovine serum albumin (BSA), and $2 \%$ normal rabbit serum (NRS), $1 \mathrm{hr}$ ], with PBS rinses in between (two times for 15 min each), incubated with goat anti-mouse CD88 antibody (Santa Cruz Biotechnology, Santa Cruz, CA) $[2 \mu \mathrm{g} / \mathrm{ml}$ in PBS,
$0.1 \%$ BSA, and $0.1 \%$ NRS (PBS-B), $1 \mathrm{hr}$ ], rinsed (PBS-B, three times for 15 min each), and incubated with rabbit anti-goat-IgG $\mathrm{F}\left(\mathrm{ab}^{\prime}\right)_{2}-\mathrm{Cy} 3$ (1: 200 in PBS-B, 1 hr; Jackson ImmunoResearch, West Grove, PA), and rinsed in PBS-B (three times for $15 \mathrm{~min}$ each) and PBS (15 min). Coverslips were mounted under moviol (Sigma).

CD88 immunodetection. Cells were surface labeled with EZ-Link sulfo- $N$-hydroxysuccinimidyl-biotin $(1 \mathrm{mg} / \mathrm{ml}$ of PBS for $30 \mathrm{~min}$ at room temperature; Pierce, Rockford, IL). After rinses with PBS, cells were lysed in extraction buffer [20 mM Tris/ $\mathrm{HCl}, \mathrm{pH} 7.3,140 \mathrm{~mm} \mathrm{NaCl}$, $0.5 \%$ Triton X-100, 150 U of DNase I (Worthington, Lakewood, NJ), and one tablet per $50 \mathrm{ml}$ of Complete protease inhibitors (Boehringer Mannheim, Mannheim, Germany) for $30 \mathrm{~min}$ ] (Hanisch et al., 2001). After freezing-thawing, anti-CD88 antibody $(6 \mu \mathrm{g} / \mathrm{ml})$ was added for $75 \mathrm{~min}$, followed by $10 \mu \mathrm{l} / \mathrm{ml}$ protein $\mathrm{A} / \mathrm{G}$ resin (ImmunoCatcher; CytoSignal, Irvine, CA). The mixture was rocked for another $30 \mathrm{~min}$ and transferred to spin filters in microcentrifuge tubes equilibrated with mild lysis solution (ImmunoCatcher). After rinses, tubes were centrifuged $(16,000 \times g$, $1 \mathrm{~min}$ ), and the resin was rinsed again, followed by centrifugation and incubation with SDS-PAGE sample buffer. After centrifugation, the filtrates were collected, and lysate aliquots (protein measured by MicroBCA assay; Pierce) were separated on a $10 \%$ SDS-PAGE gel and transferred to polyvinylidene difluoride membrane (Pierce). Membranes were blocked with BSA (5\%, $20 \mathrm{~mm}$ Tris/ $\mathrm{HCl}$ buffer, $\mathrm{pH} 7.3$, containing 150 $\mathrm{mm} \mathrm{NaCl}$, and TBS). Biotinylated CD88 was visualized with ExtrAvidin peroxidase (at $1: 100,000$, TBS, containing $0.05 \%$ Tween 20 for 90 min; Sigma), followed by ECL (Super Signal Ultra; Pierce). Another sample set underwent analysis for total CD88 protein. After blocking, membranes were incubated with anti-CD88 antibody $(1 \mu \mathrm{g} / \mathrm{ml}$ in TBS, $0.05 \%$ Tween 20 , and $10 \mathrm{mg} / \mathrm{ml} \mathrm{BSA}$ for $90 \mathrm{~min}$ ), rinsed, incubated with rabbit antigoat IgG antibody peroxidase (1:50,000 in TBS, containing Tween 20 and BSA for $60 \mathrm{~min}$; Sigma), washed, and developed by ECL.

Nitric oxid release. NO production was studied in cultures (24-well plates with $1 \times 10^{5}$ cells per well) with and without stimulation by LPS $(100 \mathrm{ng} / \mathrm{ml})$, BAPTA $(10-50 \mu \mathrm{M})$, BAPTA and LPS, and ionomycin (1$1000 \mathrm{~nm}$ ). NO was determined in the supernatants after $24 \mathrm{hr}$ by the Griess reaction as accumulated nitrite, a breakdown product of NO, using sodium nitrite as a standard. Each supernatant $(100 \mu \mathrm{l})$ was mixed with $100 \mu \mathrm{l}$ of Griess reagent and incubated at room temperature for 10 min. Optical density was determined in a microplate reader (1420 Victor; Wallac Oy, Turku, Finland) at $540 \mathrm{~nm}$ wavelength.

Cytokine and chemokine release. Microglial cytokine and chemokine release was assayed in 96-well plates with $5 \times 10^{4}$ cells per well after 6 and $24 \mathrm{hr}$ of incubation in the absence or presence of LPS $(100 \mathrm{ng} / \mathrm{ml})$, BAPTA $(50 \mu \mathrm{M})$, BAPTA and LPS, or ionomycin (1-1000 nM). Supernatant samples were analyzed for mouse tumor necrosis factor $\alpha$ (TNF $\alpha)$, interleukin-6 (IL-6), total interleukin-12 (IL-12) (collecting the IL-12 forms $\mathrm{p} 70, \mathrm{p} 40$, and $\mathrm{p} 40_{2}$ ), macrophage inflammatory protein- $1 \alpha$ (MIP$1 \alpha$ ), and $\mathrm{KC}$ [the mouse equivalent of growth-related oncogene $(\mathrm{GRO} \alpha)]$ in sandwich ELISA based on mouse- and factor-specific antibody pairs (R \& D Systems, Wiesbaden, Germany) following the procedure of the manufacturer. The color reaction was analyzed in a microplate reader (SLT, Spectra; LabInstruments Deutschland, Crailsheim, Germany). Total protein was determined using the MicroBCA protein assay (Pierce).

Viability tests. Microglial metabolic activity was assayed in 96-well plates with $5 \times 10^{4}$ cells per well using WST-1 reagent (4-[3-(4iodophenyl)-2-(4-nitrophenyl)-2 $H$-5-tetrazolio]-1,3-benzene disulfonate) (Roche Diagnostics, Mannheim, Germany) according to the instructions of the manufacturer. The assay is based on the enzymatic cleavage of WST tetrazolium salt to formazan by the succinate-tetrazolium reductase system of the respiratory chain of intact mitochondria. The color reaction was measured in a microplate reader ( 1420 Victor; Wallac Oy) at $540 \mathrm{~nm}$ wavelength after $24 \mathrm{hr}$ of incubation without and with LPS (100 $\mathrm{ng} / \mathrm{ml})$, BAPTA (50 $\mu \mathrm{M})$, BAPTA and LPS, and ionomycin (1-1000 nM).

In addition, cells were labeled by nuclear dyes to determine the amount of surviving cells after an incubation. Staining with DAPI (4,6diamidino-2-phenylindoldihydro-chlorid) (Boehringer Mannheim) showed the total amount of cells, whereas staining with ethidium bromide (Molecular Probes) revealed the number of dead microglia. Cells 
were counted in four observation fields using a fluorescence microscope (Zeiss Axioplan) with a $40 \times$ magnification (numerical aperture of 0.75 ).

Statistical analysis. The effect of treatments between groups was tested for statistical significance performing Mann-Whitney $U$ test and $\chi^{2}$ test with SPSS software (SPSS, Chicago, IL). $p<0.05$ denoted statistical significance.

\section{Results}

Activated microglial cells reveal attenuated calcium signaling To study the impact of microglial activation on receptormediated $\mathrm{Ca}^{2+}$ signaling, we compared untreated microglial cells with those incubated with LPS (100 ng/ml for $24 \mathrm{hr}$ ). LPS is commonly used as a model agent in studies on inducible microglia-macrophage functions and bacterial CNS infections (Hanisch, 2001). The LPS dose was chosen because it also relates to a clinically relevant concentration range (Hanisch et al., 2001). For eliciting transient increases in the $\left[\mathrm{Ca}^{2+}\right]_{\mathrm{i}}$, UTP and C5a were applied. Both have functional receptors on microglia, which are linked to calcium signaling, namely metabotropic purinergic receptors and CD88, respectively. In addition, initial experiments also used ATP as another and previously studied purinoreceptor ligand.

Addition of UTP $(100 \mu \mathrm{M})$ or C5a ( $2 \mathrm{nM})$ for $30 \mathrm{sec}$ to the bath solution induced reproducible transient increases in the fura-2based calcium signal. An example of a trace (R 340/380) as recorded from an individual microglial cell under control conditions is given in Figure 1A. The signal intensity and the shape of the respective $\left[\mathrm{Ca}^{2+}\right]_{\mathrm{i}}$ transients compared with previous reports (Möller et al., 2000b). However, LPS-activated microglia generated much smaller $\left[\mathrm{Ca}^{2+}\right]_{\mathrm{i}}$ signals for both of the ligands (Figs. $1 B, 2 A)$.

Averaging the recorded R 340/380 traces for a large number of control ( $n=799$ from nine independent experiments) (Fig. 1C) and LPS-activated ( $n=754$ from 10 experiments) cells (Fig. $1 D$ ) revealed a significant suppression of the receptor-evoked calcium signals, as illustrated for the response to UTP (for statistics, see Table 1). For direct comparison, an overlay of the two graphs is illustrated in Figure $1 E$. Figure $1, G$ and $H$, is amplitude histograms of the $\mathrm{Ca}^{2+}$ responses of untreated and LPS-activated cells. For each cell, the signal amplitude was calculated as the difference between the basal R 340/380 signal (average of the first 10 recorded image frames) and the respective peak level of the UTPinduced transient. According to their size, the amplitudes were then classified into ranges. As reflected by the shift of the amplitude distribution, activated microglia exhibited smaller UTPevoked increases in the $\left[\mathrm{Ca}^{2+}\right]_{\mathrm{i}}$ (Table 1$)$.

\section{Microglial activation is accompanied by an increased resting $\left[\mathrm{Ca}^{2+}\right]_{\mathbf{i}}$}

Interestingly, a comparison of the $\left[\mathrm{Ca}^{2+}\right]_{\mathrm{i}}$ traces in Figure $1 E$ revealed a marked increase in the basal level for the activated cells. Figure $1 F$ shows the values of basal $\left[\mathrm{Ca}^{2+}\right]_{\mathrm{i}}$ in untreated and LPS-activated cells as averaged from the first 10 image frames of these traces (Table 1). Apparently, the reduction in receptor signaling efficacy was paired with a general elevation in the basal $\left[\mathrm{Ca}^{2+}\right]_{\mathrm{i}}$. The smaller response amplitudes superimposed on the increased resting level in LPS-treated cells were, however, not attributable to technical limitations in recording higher R 340/ 380 values. The cells did not reach a ceiling level of fluorescence, because amplitudes with higher maximal ratios were recorded in control cells.
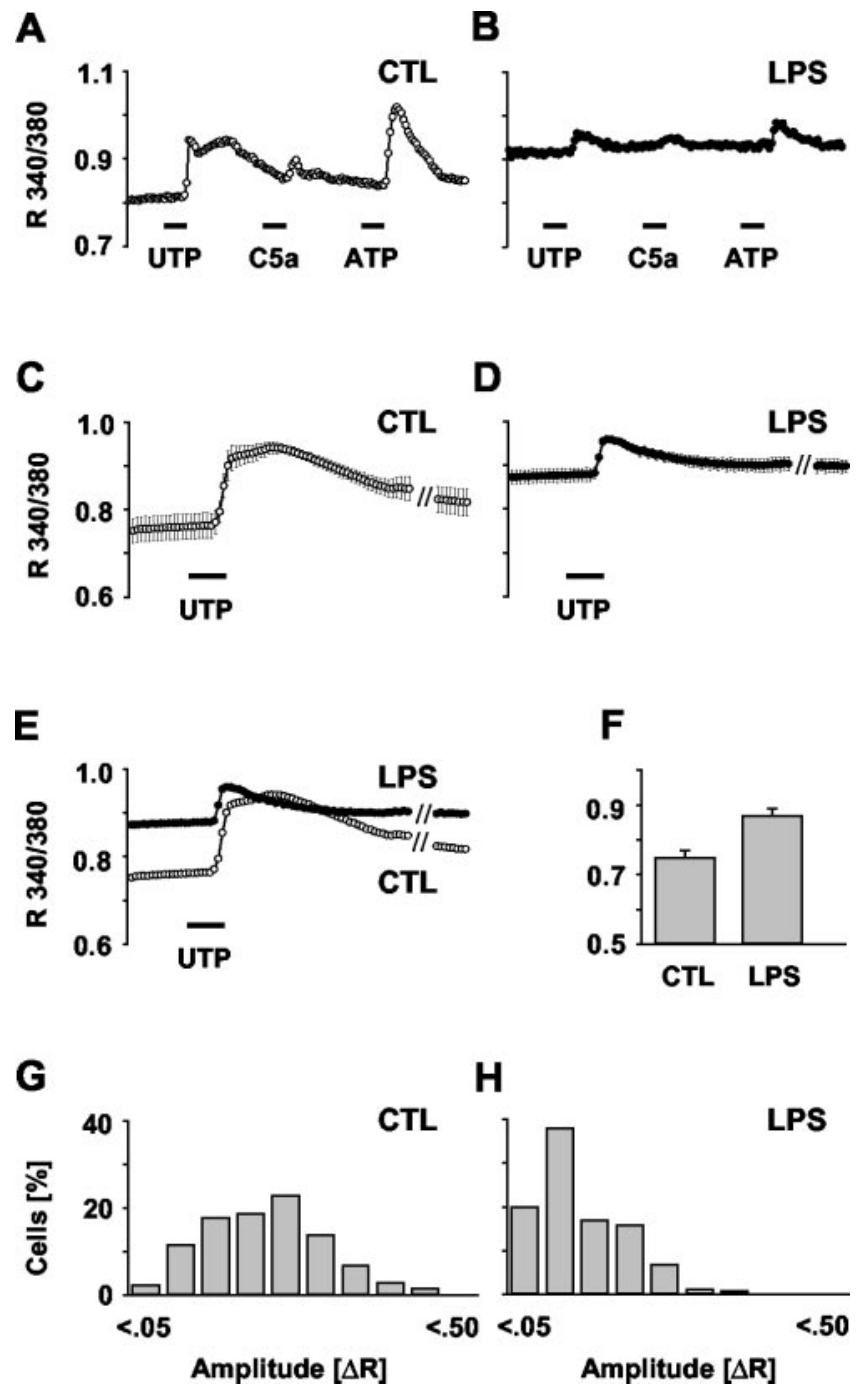

Figure 1. Rise in basal $\left[\mathrm{Ca}^{2+}\right]_{i}$ and attenuation of receptor-evoked $\mathrm{Ca}^{2+}$ signaling during microglial activation. Microglial calcium signaling in response to UTP and C5a application was compared between LPS-activated ( $100 \mathrm{ng} / \mathrm{ml}, 24 \mathrm{hr}$ ) and untreated cells (CTL). Using fura-2based imaging, $\left[\mathrm{Ca}^{2+}\right]_{i}$ was measured as the ratio of fluorescence at 340 and $380 \mathrm{~nm}(\mathrm{R}$ 340/380). For eliciting calcium transients, UTP (100 $\mu \mathrm{M})$, C $5 \mathrm{a}(2 \mathrm{~nm})$, and ATP (100 $\mu \mathrm{M})$ were added to the bath solution for $30 \mathrm{sec}$ (bars, position indicating application, i.e., switch to the corresponding bath solution). $A, B$, Representative $\left[\mathrm{Ca}^{2+}\right]_{\mathrm{i}}$ traces of a control and a LPSstimulated cell. C, D, Average $\left[\mathrm{Ca}^{2+}\right]_{\mathrm{i}}$ traces in control and LPS-stimulated cells as summarized from 9 and 10 independent experiments with a total of $n=799$ and $n=754$, respectively. Data are given as mean $\pm S E M$. E, Overlay of the traces in Cand D revealing the reduction in the signal amplitude and the concomitant increase in basal $\left[\mathrm{Ca}^{2+}\right]_{i}$ during LPS activation. $F$, Comparison of the average basal $\left[\mathrm{Ca}^{2+}\right]_{\mathrm{i}}$ in control and LPS-treated microglia as calculated from the first 10 image frames of the cells in E. Data are mean \pm SEM. G, H, Histograms of UTP-evoked $\left[\mathrm{Ca}^{2+}\right]_{i}$ signal amplitudes in the control and LPS-stimulated cells (as for $($ and $D$ ). Amplitudes were calculated as the difference between basal (average of the first 10 recorded image frames) and peak $R 340 / 380$ values of each individual cell $(\Delta R)$. Values of $\Delta R$ were classified into 10 ranges $(0 \leq \Delta R<0.05,0.05 \leq \Delta R<0.10$, etc.). The histogram for the LPS-activated cells clearly shows a shift to smaller values.

\section{Surface expression of C5a receptors is not affected during microglial activation}

Attenuated signal intensity could be attributable to a downregulation of the respective receptor. We thus determined whether receptor expression was altered during LPS treatment. We focused on the receptor for C5a because it consists of a single protein, CD88, allowing for a convenient expression analysis. In contrast, UTP binds to a heterogeneous population of metabotropic 
A

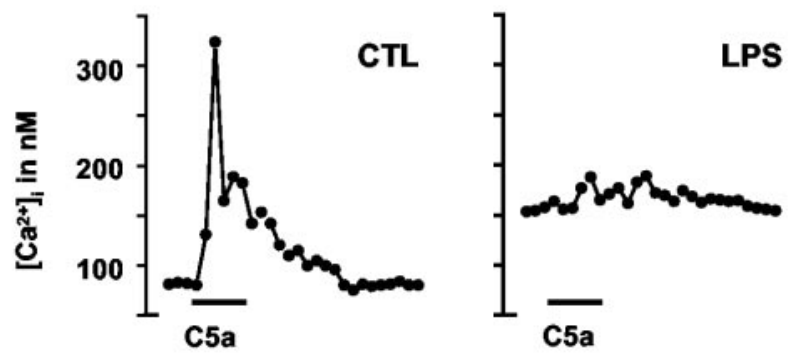

B
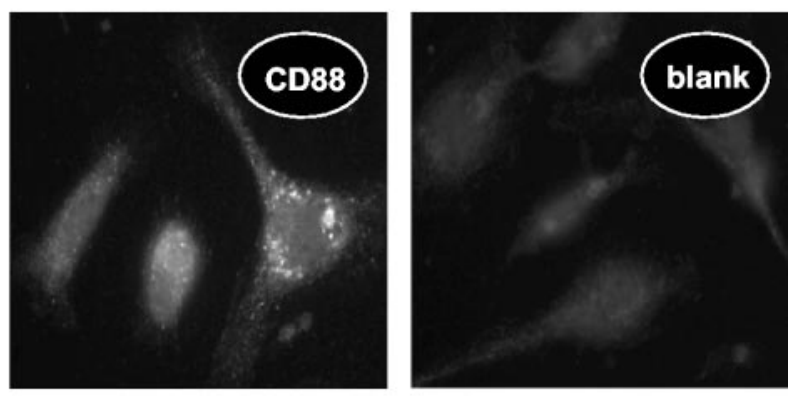

C

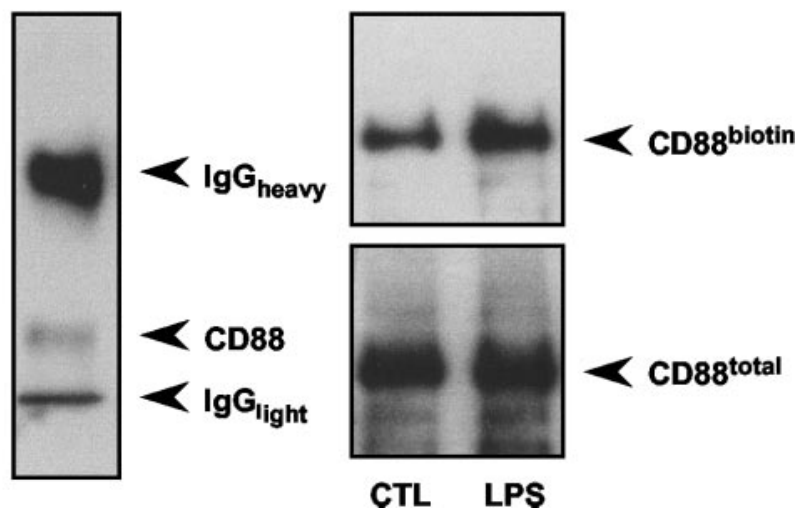

Figure 2. Complement $\mathrm{C} 5 \mathrm{a}$-induced calcium signaling and expression of $\mathrm{C} 5 \mathrm{a}$ receptors (CD88) in microglia. $A$, To evoke $\left[\mathrm{Ca}^{2+}\right]_{\mathrm{i}}$ transients, cells were stimulated with $C 5 \mathrm{a}$ by bath application ( 2 nm, 30 sec; see bars). Calcium concentrations (nanomolar) were calculated from fura-2-based fluorescence signals using calibration curves. The two traces illustrate representative recordings from individual microglial cells, as sampled from control cultures (CTL) and cultures after a treatment with LPS (100 ng/ml, $24 \mathrm{hr})$. LPS-activated cells revealed a marked suppression of the signal amplitude along with an increased basal $\left[\mathrm{Ca}^{2+}\right]_{\mathrm{i}}(191 \mathrm{~nm}, n=25 \mathrm{vs}$ $68 \mathrm{~nm}$ for the control, $n=28)$. $B$, The micrographs illustrate an anti-CD88 immunofluorescence staining of the $(5$ a receptor in normal (untreated) microglial cells, revealing constitutive expression. Control staining (blank) omitting the primary antibody resulted in diffuse background fluorescence only. C, Blot images show the results of CD88 immunoprecipitations from microglial cultures. Immunoblotting revealed a single protein band in lysates of untreated microglia (left), the apparent molecular weight being slightly smaller than expected. Note that the heavy and light chains of the precipitating anti-CD88 IgG were also visualized by the staining protocol using the same antibody for capturing and detection. To label membrane-associated CD88 in microglia of LPS-treated (100 ng/ml, $24 \mathrm{hr}$ ) and control cultures, cell surface proteins were biotinylated using a cell-impermeable $N$-hydroxysuccinimidyl derivative of biotin. Total CD88 protein was immunoprecipitated from the cellular lysates and immunodetected by anti-CD88 antibody. The biotinylated fraction of CD88 was separately stained using a streptavidin conjugate. The comparison of material obtained from untreated and LPS-treated cells suggested that neither the total CD88 nor the biotin-labeled fraction changed during microglial activation. Blots represent one of four experiments.
Table 1. Statistical evaluation of $\left[\mathrm{Ca}^{2+}\right]_{i}$ measurements in microglial cells

\begin{tabular}{|c|c|c|c|c|}
\hline \multirow[b]{2}{*}{ Comparison } & \multicolumn{2}{|c|}{ Basal $\left[\mathrm{Ca}^{2+}\right]_{\mathrm{i}}^{a}$} & \multicolumn{2}{|c|}{ Signal amplitudes ${ }^{b}$} \\
\hline & $p$ value & Rating $^{c}$ & $p$ value & Rating $^{c}$ \\
\hline CTL-LPS & 0.001 & $* * *$ & 0.000 & $* * *$ \\
\hline CTL-BAPTA & 0.423 & NS & 0.159 & NS \\
\hline CTL-BAPTA + LPS & 0.400 & NS & 0.000 & $* * *$ \\
\hline CTL-ionomycin & 0.018 & $*$ & 0.000 & $* * *$ \\
\hline LPS-BAPTA & 0.009 & ** & 0.000 & *** \\
\hline LPS-BAPTA + LPS & 0.002 & ** & 0.000 & *** \\
\hline LPS-ionomycin & 0.313 & NS & 0.000 & $* * *$ \\
\hline BAPTA-BAPTA + LPS & 0.965 & NS & 0.000 & *** \\
\hline BAPTA-ionomycin & 0.043 & * & 0.000 & $* * *$ \\
\hline BAPTA + LPS-ionomycin & 0.016 & * & 0.000 & $* * *$ \\
\hline
\end{tabular}

${ }^{a}$ Mann-Whitney U test.

${ }^{b} \chi^{2}$ test.

Level of significance, from NS (not significant) to ${ }^{* * *}$ (highly significant).

purinoreceptors (Ralevic and Burnstock, 1998). Immunocytochemical staining for CD88 revealed a punctuated distribution on microglia (Fig. 2B). Combination of biotin labeling of cell surface molecules with subsequent anti-CD88 immunoprecipitation revealed that neither the total nor the membrane-inserted amounts of CD88 were affected by the LPS treatment (Fig. 2C).

LPS-induced changes in calcium signaling and basal $\left[\mathrm{Ca}^{2+}\right]_{\mathrm{i}}$ can be reversed by treatment with BAPTA

To test for a correlation between the elevated basal $\left[\mathrm{Ca}^{2+}\right]_{\mathrm{i}}$ and the impaired calcium signaling, we treated control and LPSactivated cells with the intracellular calcium chelator BAPTA. We used $50 \mu \mathrm{M}$, a concentration efficient to affect LPS-induced release activity (shown below). Averaging the recorded R 340/380 traces of cells loaded with BAPTA only $(n=705$ from eight independent experiments) (Fig. $3 A$ ) revealed no significant difference from untreated controls (Fig. 1C). The UTP response amplitude as an indicator of the signaling capacity was not altered (Fig. 3E, Table 1). This could be confirmed by also comparing the amplitude histograms of UTP responses in the presence and absence of BAPTA (compare with Fig. $3 G$ ). Thus, BAPTA did not impair calcium signaling.

In contrast, the averaged trace of cells treated with LPS in the presence of BAPTA ( $n=591,10$ experiments) (Fig. $3 B$ ) showed a marked difference compared with cells exposed to LPS alone (Fig. 3C, Table 1). Cells treated with LPS in the presence of BAPTA did not show the otherwise LPS-inducible rise in basal $\left[\mathrm{Ca}^{2+}\right]_{\mathrm{i}}($ Fig. $3 D)$. The basal $\left[\mathrm{Ca}^{2+}\right]_{\mathrm{i}}$ equaled control conditions. Moreover, the LPS-induced shift toward smaller amplitudes (Fig. $3 \mathrm{H}$ ) was much less prominent in the presence of BAPTA (Fig. $3 F$ ), indicating partially restored signaling ability. These results suggest that moderate chelation of intracellular calcium could, indeed, revert the activation-induced decrease in signaling efficacy.

Treatment with ionomycin can mimic the LPS-induced changes in calcium signaling and basal $\left[\mathrm{Ca}^{2+}\right]_{\mathrm{i}}$

To test our hypothesis that the attenuated signaling ability in activated microglia was attributable to the concomitant rise in basal $\left[\mathrm{Ca}^{2+}\right]_{\mathrm{i}}$, we induced an elevation of the basal $\left[\mathrm{Ca}^{2+}\right]_{\mathrm{i}}$ by applying the calcium ionophor ionomycin. We postulated that an ionomycin-mediated influx of calcium into the cytosol should then hamper the signaling capacity. UTP stimulation of ionomycin-treated cells should yield signaling amplitudes comparable with those of LPS-treated cells. Indeed, ionomycin loading did not only cause the expected increase in basal $\left[\mathrm{Ca}^{2+}\right]_{\mathrm{i}}$ (Fig. 
A

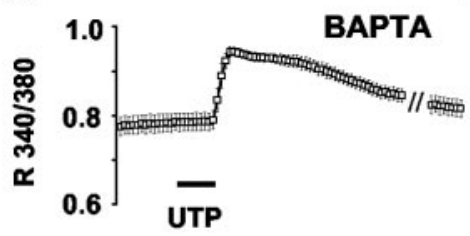

B

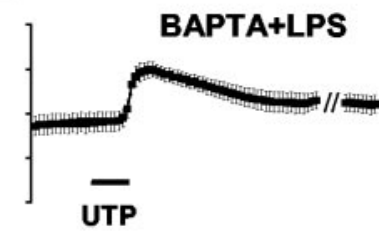

C

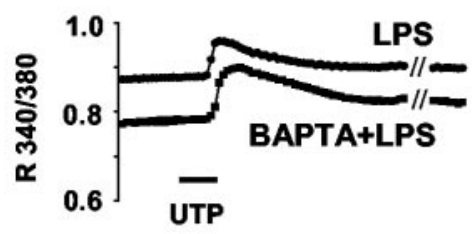

D

E

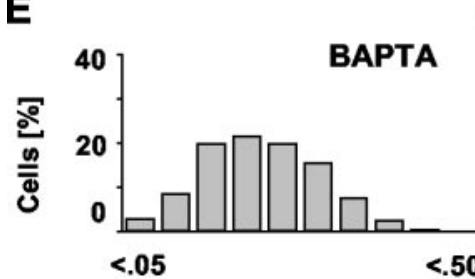

Amplitude $[\Delta R]$

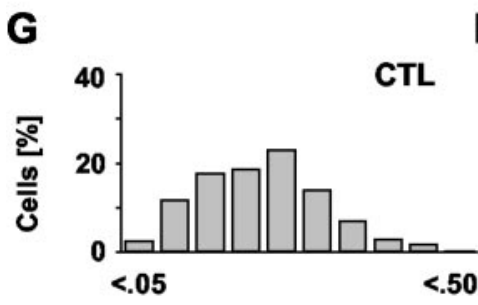

Amplitude $[\Delta R]$

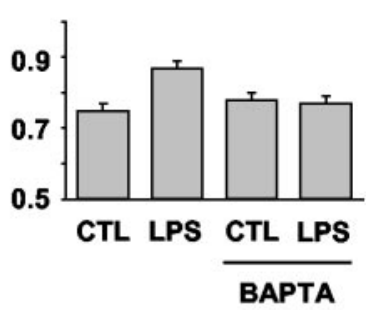

$\mathbf{F}$

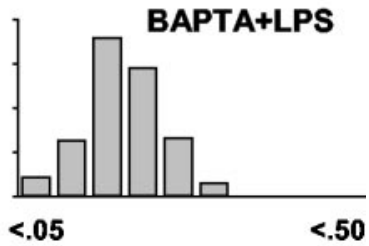

Amplitude $[\Delta \mathbf{R}]$

$\mathbf{H}$

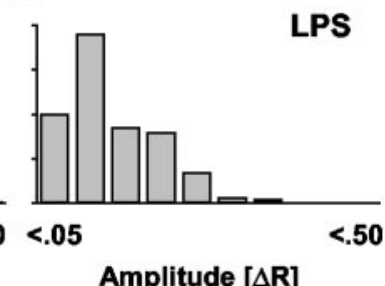

Figure 3. Influence of intracellular $\mathrm{Ca}^{2+}$ chelation on basal $\left[\mathrm{Ca}^{2+}\right]_{\mathrm{i}}$ and UTP-evoked $\mathrm{Ca}^{2+}$ signals. Microglial cultures were incubated with BAPTA AM $(50 \mu \mathrm{m}, 24 \mathrm{hr})$ in the absence or presence of LPS (100 ng/ml), and [ $\left[\mathrm{Ca}^{2+}\right]_{i}$ was measured as R 340/380 (Fig. 1). Calcium transients were elicited by stimulation with UTP $(100 \mu \mathrm{m}, 30 \mathrm{sec}) . A, B$, Average $\left[\mathrm{Ca}^{2+}\right]_{\mathrm{i}}$ traces in BAPTA-treated and BAPTA plus LPS-treated cells were calculated from 8 and 10 independent experiments with a total of $n=705$ and $n=591$, respectively. Data are given as mean \pm SEM. C, Overlay of the traces obtained from LPS treatment only (Fig. 1D) and from the combined treatment with BAPTA plus LPS $(B)$ showing a prevention of the activation-mediated rise in basal $\left[\mathrm{Ca}^{2+}\right]_{\mathrm{i}}$ along with a partially restored $\left[\mathrm{Ca}^{2+}\right]_{\mathrm{i}}$ transient. D, Comparison of the average basal $\left[\mathrm{Ca}^{2+}\right]_{\mathrm{i}}$ in control (CTL) and LPS-treated microglia as obtained with or without BAPTA presence. Values were calculated as described in Figure 1. E, F, Histograms of UTP-evoked $\left[\mathrm{Ca}^{2+}\right]_{i}$ signal amplitudes $(\Delta R)$ in the cells under BAPTA (as in $A$ ) and cells with combined BAPTA-LPS treatment (as in $B$ ). Amplitudes were calculated and classified as outlined in Figure 1. For a direct comparison, the situations in control and LPS-stimulated cells are shown again (G, $H$ ). The histograms reveal that BAPTA presence during the LPS challenge of microglia partially prevented the activation-associated shift to smaller $\Delta R$ values.

$4 C$, Table 1 ), as similarly seen with LPS treatment. Moreover, the averaged trace of the UTP-evoked $\left[\mathrm{Ca}^{2+}\right]_{\mathrm{i}}$ signal $(n=515$, six experiments) (Fig. 4A) demonstrated a clear reduction of the response peak when compared with untreated controls (Fig. $4 B$, Table 1). Finally, histograms revealed a similar shift toward smaller signaling amplitudes, as it was observed with LPSactivated cells (Fig. 4D). Together, these results confirmed our assumption that elevated basal $\left[\mathrm{Ca}^{2+}\right]_{\mathrm{i}}$ as associating with microglial activation may lead to attenuated receptor-evoked calcium signaling.
A

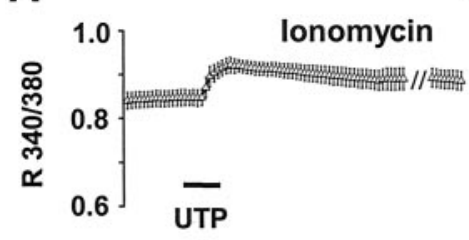

B

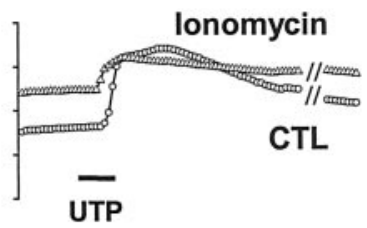

C

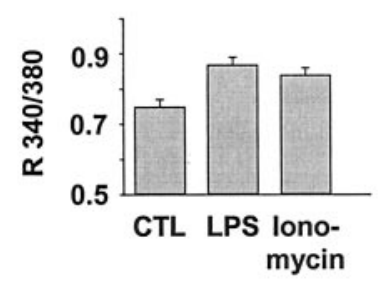

D

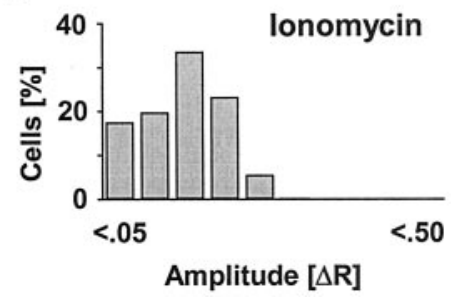

Figure 4. Influence of an ionophore-induced elevation of the basal $\left[\mathrm{Ca}^{2+}\right]_{i}$ on UTP-evoked $\mathrm{Ca}^{2+}$ signals. Microglial cultures were incubated with ionomycin $(1 \mu \mathrm{m}, 24 \mathrm{hr})$, and $\left[\mathrm{Ca}^{2+}\right]_{\mathrm{i}}$ was measured as R340/380. Calcium transients were elicited by stimulation with UTP (100 $\mu \mathrm{m}$, $30 \mathrm{sec}) . A$, Average $\left[\mathrm{Ca}^{2+}\right]_{\mathrm{i}}$ trace in ionomycin-treated cells calculated from six independent experiments with a total of $n=515$. Data are given as mean \pm SEM. $B, 0$ verlay of the average traces of ionomycin-treated and control (CTL) microglia (Fig. 1C) showing an elevated $\left[\mathrm{Ca}^{2+}\right]_{\mathrm{i}}$ together with a reduced amplitude of the receptor-evoked $\left[\mathrm{Ca}^{2+}\right]_{\mathrm{i}}$ transient. $C$, Quantification of the basal $\left[\mathrm{Ca}^{2+}\right]_{i}$ of ionomycin-treated microglia compared with the LPS and control groups (Fig. 1F).D, Histogram of UTP-evoked $\left[\mathrm{Ca}^{2+}\right]_{i}$ signal amplitudes $(\Delta \mathrm{R})$ in cells after ionomycin treatment (as in $A$ ). Amplitudes were calculated and classified as described in Figure 1. The histogram indicates a shift of the $\Delta R$ to smaller values as similarly obtained from LPS-activated cells (Fig. 1H).

LPS-induced NO and cytokine-chemokine release activities are reduced in the presence of BAPTA

Chronic elevation of the basal $\left[\mathrm{Ca}^{2+}\right]_{\mathrm{i}}$ after LPS activation could be a central event in the microglial activation process. Therefore, we tested whether microglial release activities in response to LPS challenge were influenced by the basal $\left[\mathrm{Ca}^{2+}\right]_{\mathrm{i}}$ level. We prevented the LPS-inducible elevation of basal $\left[\mathrm{Ca}^{2+}\right]_{i}$ by BAPTA administration and determined the outcomes for the production of NO, as well as the release of certain cytokines and chemokines, i.e., characteristic executive features of activated microglia.

Stimulation with LPS led to the expected strong increase in NO production compared with untreated controls (Fig. 5A). BAPTA treatment by itself did not have any effect. However, in the presence of BAPTA, the LPS-induced NO production was significantly reduced in a concentration-dependent manner as of $10 \mu \mathrm{M}$ (Fig. 5A). Indeed, the release under $50 \mu \mathrm{M}$ BAPTA declined to control levels (Table 2).

Similarly, BAPTA affected the release of certain cytokines and chemokines (Fig. 5B). LPS caused the extracellular accumulation of the cytokines TNF $\alpha$, IL-6, and IL-12, as well as of the chemokines $\mathrm{KC}$ (the rodent equivalent of GRO $\alpha$ ) and MIP- $1 \alpha$. Supernatants of untreated cultures were virtually devoid of any of these cytokines and chemokines. In the presence of BAPTA, the release of some factors was strongly suppressed, whereas that of others was only slightly attenuated. IL-12 appeared to be most and MIP- $1 \alpha$ least affected by the BAPTA-mediated prevention of LPS-induced $\left[\mathrm{Ca}^{2+}\right]_{\mathrm{i}}$ elevation. The individual release reduction was similar at the two time points studied during an ongoing LPS-BAPTA treatment, i.e., $6 \mathrm{hr}$ and $24 \mathrm{hr}$.

To exclude toxic BAPTA effects, metabolic activity was monitored using the WST-based viability assay (Fig. 5C). BAPTA, 
A

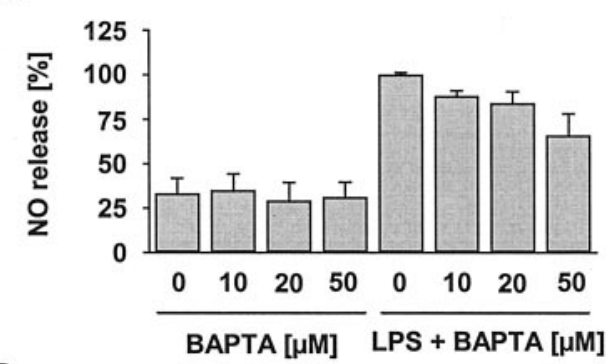

B

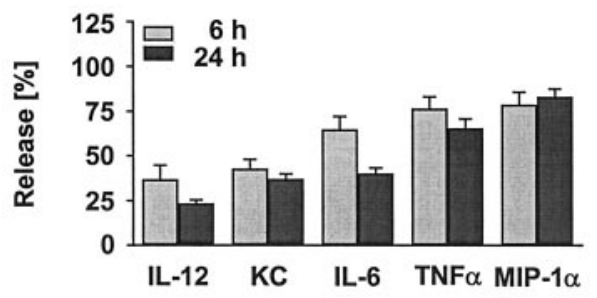

C

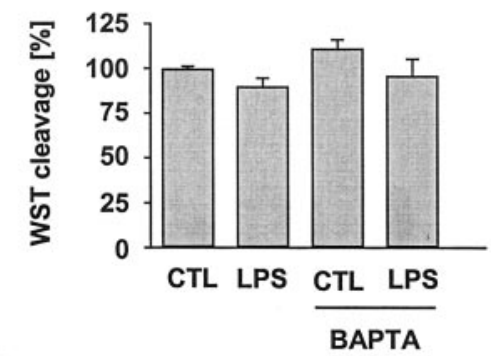

D

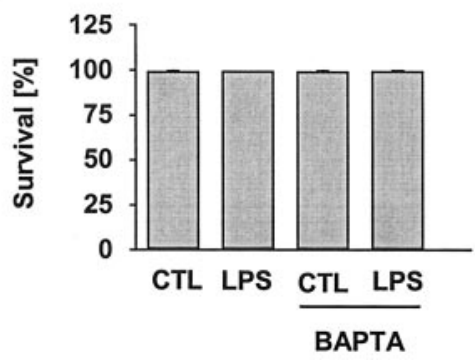

Figure 5. Effect of intracellular $\mathrm{Ca}^{2+}$ chelation on the basal and LPS-induced release of NO and cytokines-chemokines, as well as on cell viability. Microglial cultures were treated with varying concentrations of BAPTA AM in the absence or presence of $\mathrm{LPS}(100 \mathrm{ng} / \mathrm{ml}, 24 \mathrm{hr}) . A, \mathrm{NO}$ release measured as nitrite accumulation in the culture supernatant was determined and expressed as percentage of the amount obtained from LPS treatment only. BAPTA reduced the LPS-induced NO production. Data are the mean \pm SEM from at least three independent experiments performed in triplicate. $B$, Cytokine and chemokine release in LPS-activated microglial cultures in the presence of BAPTA $(50 \mu \mathrm{m})$. Release values were determined as of 6 and $24 \mathrm{hr}$ and expressed as percentage of the respective value obtained from LPS treatment only. BAPTA presence had a rather variable influence on individual factors, showing moderate to marked reduction. Data are the mean \pm SEM from three experiments ( $n=36$ per group). C, Effect of BAPTA ( $50 \mu \mathrm{m}, 24 \mathrm{hr}$ ) on the cleavage of WST- 1 by mitochondrial enzymes in control (CTL) and LPS-treated microglia. Data are the mean \pm SEM from six experiments ( $n=69$ per group). $D$, Effect of BAPTA ( $50 \mu \mathrm{m}, 24 \mathrm{hr}$ ) on the survival of control and LPS-treated microglia as determined by a life- death staining assay. Data are the mean \pm SEM from three experiments run in duplicate. No BAPTA-related difference was detected by either of the vitality assays.

even at the highest concentration used for the calcium imaging $(50 \mu \mathrm{M})$, did not show any change in the mitochondrial WST cleavage activity (Fig. 5C). Similarly, life-death staining of BAPTA AM-exposed microglia did not reveal impaired survival
Table 2. Statistical evaluation of N0-release measurements in microglial cells

\begin{tabular}{lll}
\hline & N0 release & \\
\cline { 2 - 3 } Comparison & $p$ value & Rating $^{b}$ \\
\hline CTL-LPS & 0.008 & $* *$ \\
CTL-LPS + BAPTA $(10 \mu \mathrm{m})$ & 0.016 & $*$ \\
CTL-LPS + BAPTA $(20 \mu \mathrm{m})$ & 0.036 & $*$ \\
CTL-LPS + BAPTA $(50 \mu \mathrm{m})$ & 0.095 & NS \\
LPS-LPS + BAPTA $(10 \mu \mathrm{m})$ & 0.016 & $*$ \\
LPS-LPS + BAPTA $(20 \mu \mathrm{m})$ & 0.036 & $*$ \\
LPS-LPS + BAPTA $(50 \mu \mathrm{m})$ & 0.008 & $*$ \\
\hline${ }^{a}$ Mann-Whitney U test. & & \\
${ }^{b}$ Level of significance, from NS (not significant) to ${ }^{* * *}$ (highly significant).
\end{tabular}

(Fig. 5D). In addition, examination of the microglial gross morphology did not indicate any BAPTA-induced alteration when compared with the corresponding control situations (Fig. 6). Thus, the observed decrease in release activities was unlikely to be related to a reduced amount or vitality of cells.

These results indicate that a rise in basal $\left[\mathrm{Ca}^{2+}\right]_{\mathrm{i}}$ during microglial activation is necessary for effective induction of NO, as well as cytokines and chemokines. Nevertheless, it is not a mandatory prerequisite for these features per se, because certain cytokines and chemokines were less affected by BAPTA than others. In addition, the fact that both soluble mediator "systems," i.e., NO (as a diffusible gas) and cytokines-chemokines (as polypetides-proteins), were sensitive to BAPTA further points to some implication of $\left[\mathrm{Ca}^{2+}\right]_{i}$ in the proximal steps of the induction cascades rather than an interference with later steps of release performance.

Treatment with ionomycin cannot induce microglial release The ionomycin-induced rise in basal $\left[\mathrm{Ca}^{2+}\right]_{\mathrm{i}}$ had caused an LPSlike effect on the UTP signaling, i.e., it attenuated $\mathrm{Ca}^{2+}$ responses (Fig. 4). Assuming that an elevation of the basal $\left[\mathrm{Ca}^{2+}\right]_{\mathrm{i}}$ is a crucial step toward microglial release activities, we also tested whether ionomycin treatment was sufficient to induce NO and cytokine-chemokine production. However, none of the tested concentrations was able to induce any release (Fig. $7 A, B$ ). This failure was not attributable to toxic effects, because mitochondrial WST cleavage remained unchanged (Fig. 7C). In addition, the survival rates of microglia in culture were found to be unaffected (Fig. 7D). Finally, microscopic inspection of the cells did not reveal signs of damage, although the morphology resembled the appearance of LPS-challenged microglia (Fig. 6). The results thus render unlikely that a lifting of the basal $\left[\mathrm{Ca}^{2+}\right]_{\mathrm{i}}$ alone could cause the production of NO or the initiation of cytokinechemokine induction pathways.

\section{Discussion}

Microglial activation is associated with an increase in the resting $\left[\mathrm{Ca}^{2+}\right]_{i}$

We found that exposure of microglia to LPS caused a significant increase in the resting $\left[\mathrm{Ca}^{2+}\right]_{\mathrm{i}}$. Chronic elevations in the basal $\left[\mathrm{Ca}^{2+}\right]_{\mathrm{i}}$ level of up to $1 \mathrm{~d}$ have not yet been reported for microglia but have been described for other CNS cell types. In cortical neurons, amyloid $\beta$ treatment leads to increased $\left[\mathrm{Ca}^{2+}\right]_{\mathrm{i}}$ and thereby to enhanced excitotoxicity (Mattson et al., 1992). Astrocytes from trisomy 16 mice, a model of human trisomy 21 (Down syndrome), show abnormal calcium homeostasis with drastically increased $\left[\mathrm{Ca}^{2+}\right]_{\mathrm{i}}$ at rest (Bambrick et al., 1997). A finding similar to our observation was reported for rat mesenteric arteries. Basal $\left[\mathrm{Ca}^{2+}\right]_{\mathrm{i}}$ was higher in vessels from LPS-treated animals compared with controls (Martinez et al., 1996). In contrast, treatment 

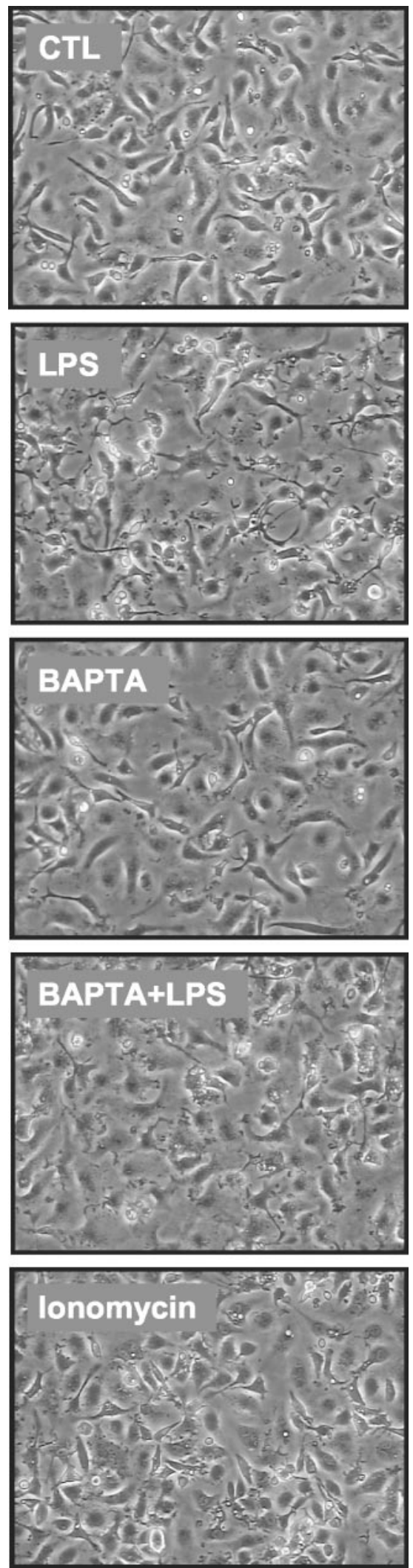

Figure 6. Morphology of microglial cells under LPS, BAPTA, and ionomycin treatment. Microglial cultures were treated for $24 \mathrm{hr}$ with LPS $(100 \mathrm{ng} / \mathrm{ml})$, BAPTA AM $(50 \mu \mathrm{M})$, a combination of BAPTA and LPS, or ionomycin $(1 \mu \mathrm{m})$. Untreated cultures served as control (CTL). Images demonstrate the appearance of cells in phase-contrast microscopy. During LPS treatment, cells revealed the characteristic gross morphology known for activated cells in vitro, including shape changes, granulation, and membrane ruffling.
A

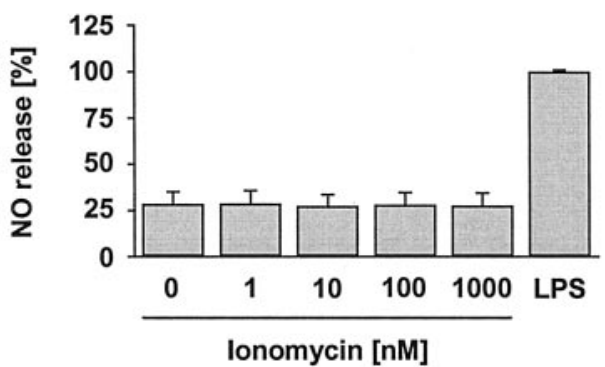

B

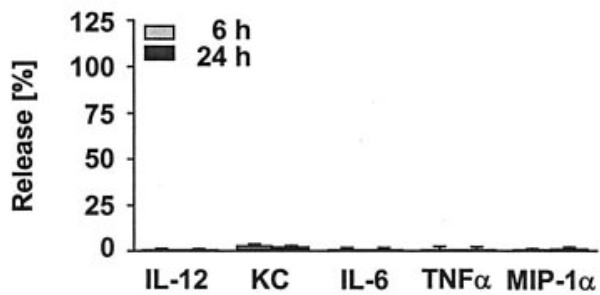

C

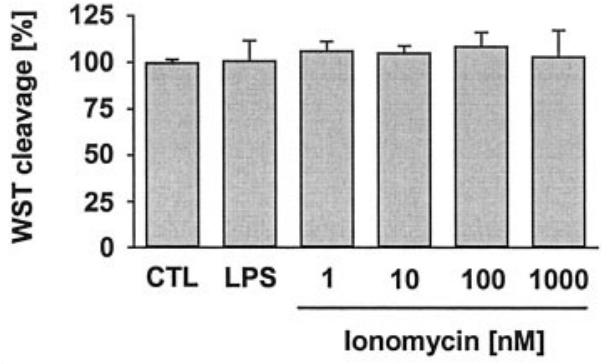

D

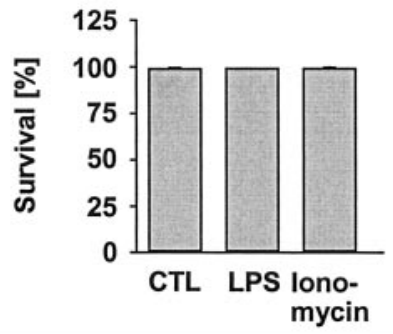

Figure 7. Effect of an ionophore-induced elevation of the basal $\left[\mathrm{Ca}^{2+}\right]_{\mathrm{i}}$ on the basal and LPS-induced release of $\mathrm{NO}$ and cytokines-chemokines, as well as on cell viability. Microglial cultures were treated with varying concentrations of ionomycin or with $\operatorname{LSS}(100 \mathrm{ng} / \mathrm{ml}, 24 \mathrm{hr})$. Release of NO $(A)$ and cytokines-chemokines $(B)$ was determined as described in Figure 5. Ionomycin did not induce any of the factors at any concentration (data for cytokines-chemokines are shown here only for ionomycin at $1 \mu \mathrm{M}$ ). Data are the mean $\pm \operatorname{SEM}$ from four $(A)$ and three $(B)$ experiments, with an average of $n=12$ and $n=36$ per group, respectively. Ionomycin also had no influence on the vitality of microglial cultures as determined by WST-1 cleavage ( $C$ and life-death staining ( $D$; data shown for $1 \mu \mathrm{m}$ of the ionophore). Data are the mean \pm SEM from three experiments, each with an average of $n=36(C)$ and $n=6(D)$ per group. CTL, Control.

of the macrophage-like cell line P338D. 1 with LPS for $8 \mathrm{hr}$ rather led to a reduction in the resting $\left[\mathrm{Ca}^{2+}\right]_{\mathrm{i}}$, whereas shorter activation periods had no consequence (Lowry et al., 1999). Moreover, LPS treatment of osteoblasts did not alter basal $\left[\mathrm{Ca}^{2+}\right]_{\mathrm{i}}$ (Tam et al., 1998). Apparently, the consequences of LPS signaling for the intracellular calcium are not uniform and may depend on the cell type.

Little is known as to the mechanism linking proximal receptor events of the LPS signaling to the regulation of calcium ho- 

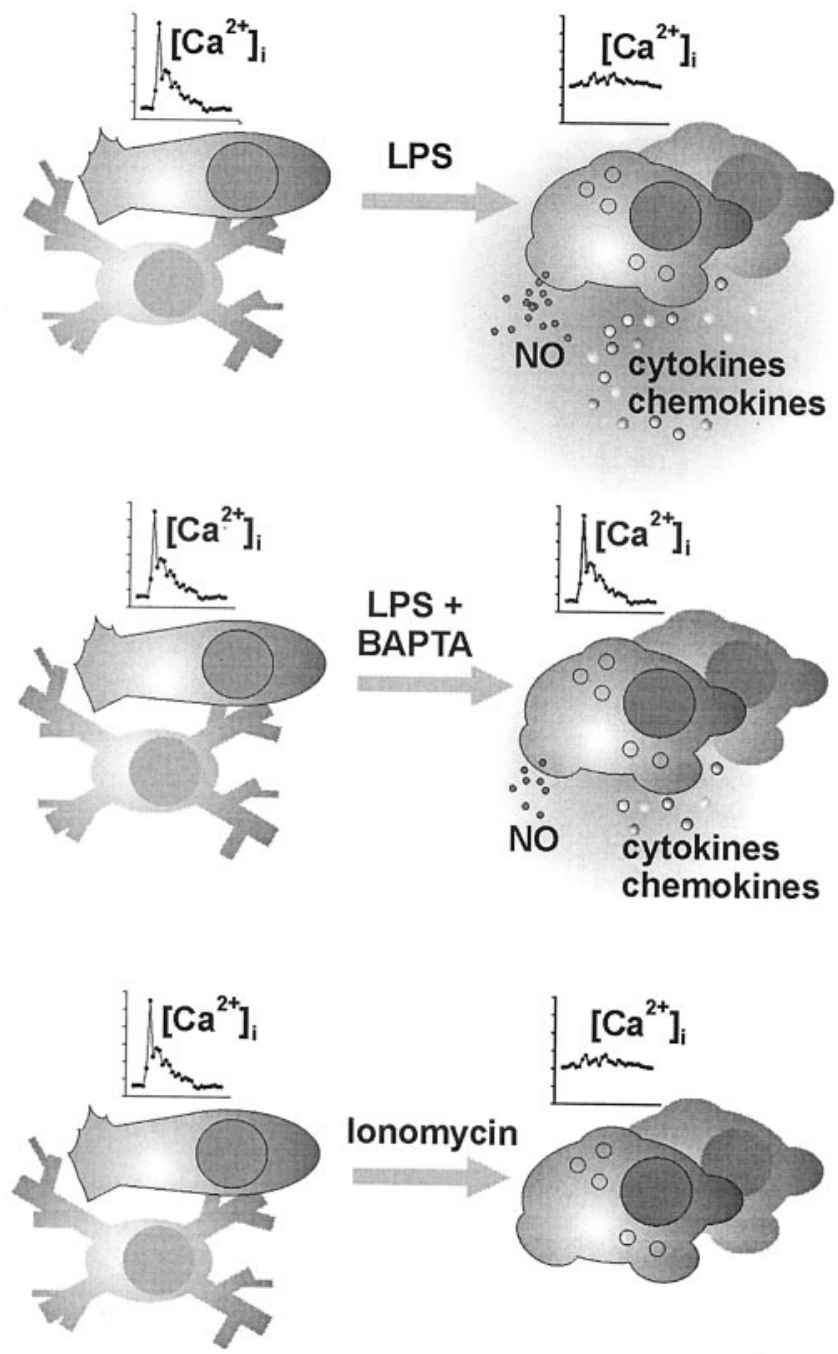

Figure 8. Schematic summary of the experimentally induced adaptations of microglia. Unstimulated microglial cells (shown on the left) in vitro typically appearing with a shortprocessed, nonbranched or rod-shaped morphology responded to UTP and C5a receptor stimulation with the generation of a $\left[\mathrm{Ca}^{2+}\right]_{i}$ transient but did not show signs of release activity, similar to the "resting" ramified microglia of the normal brain tissue. A challenge of these cells under pathological conditions, as mimicked here by a treatment with bacterial LPS, led to a complex morphological and functional transformation known as microglial activation. In the present study, LPS-activated cells were characterized by an elevated basal $\left[\mathrm{Ca}^{2+}\right]_{i}$ level along with a suppressed ability to generate receptor-triggered $\left[\mathrm{Ca}^{2+}\right]_{i}$ signals. Strong release of N0 as well as cytokines and chemokines was measured. LPS treatment in the presence of BAPTA nearly restored the receptor signaling efficacy, paralleled by an almost back-to-normal basal $\left[\mathrm{Ca}^{2+}\right]_{i}$ and an attenuated release performance. 0 n the other hand, direct enforcement of a rise in basal $\left[\mathrm{Ca}^{2+}\right]_{\mathrm{i}}$ by microglial incubation with ionomycin also suppressed the signal amplitudes but failed to trigger an LPS-like release pattern. Together, these observations suggest that an elevated basal $\left[\mathrm{Ca}^{2+}\right]_{i}$ participates in the functional adjustment of activated microglia, without being the sole cytosolic control element for executive features, such as NO and cytokine-chemokine production.

meostasis. Conceivably, an elevated basal $\left[\mathrm{Ca}^{2+}\right]_{\mathrm{i}}$ could result from enhanced constitutive $\mathrm{Ca}^{2+}$ influx, from a reduced activity of $\mathrm{Ca}^{2+}$ extrusion pumps, or from a reduction in $\mathrm{Ca}^{2+}$ buffer activity. Indeed, a chronically increased $\mathrm{Ca}^{2+}$ influx can be triggered in microglia during massive depletion of cytoplasmic stores (Toescu et al., 1998). LPS in conjunction with LPS binding protein binds to the CD14-Toll-like receptor complex to induce cytosolic signaling and nuclear events (Schumann et al., 1990; Ulevitch and Tobias, 1995; Kirschning et al., 1998; Guha and
Mackman, 2001). Several kinases and phosphorylation cascades have been shown to be recruited (Ulevitch and Tobias, 1995; Guha and Mackman, 2001; Hanisch et al., 2001). However, there is yet no evidence for direct LPS effects on $\mathrm{Ca}^{2+}$ pumps.

Activated microglial cells show an attenuated calcium signaling Whereas LPS treatment resulted in an increased basal $\left[\mathrm{Ca}^{2+}\right]_{\mathrm{i}}$, the activated cells showed a decreased responsiveness to external stimulation with UTP. We described previously that microglial activation resulted in a reduced diversity of purinoreceptor signaling (Möller et al., 2000b). Now, we could correlate the lifting in basal $\left[\mathrm{Ca}^{2+}\right]_{\mathrm{i}}$ to a suppressed purinoreceptor signaling (Fig. 8).

Moreover, we also studied another microglial ligand-receptor system, i.e., C5a signaling through its receptor CD88 (Gasque et al., 1997; Möller et al., 1997; Nataf et al., 1999; Van Beek et al., 2000). Similar to purinergic signaling, C5a responses revealed the very same principle of regulation with elevated basal $\left[\mathrm{Ca}^{2+}\right]_{\mathrm{i}}$ and reduced amplitudes after treatment with LPS. In addition, CD88 as the sole receptor for $\mathrm{C} 5 \mathrm{a}$ allowed for the convenient demonstration that the amount of membrane-expressed receptor protein was not altered by LPS treatment, suggesting that attenuated C5a responsiveness was not attributable to a decrease in receptors.

Adaptation of the calcium signaling behavior appears to be a widespread phenomenon. LPS treatment of C6 glioma cells led to an inhibition of serotonin- and thrombin-evoked signaling (Tawara et al., 1998). In osteoblasts, LPS activation altered parathyroid hormone- and prostaglandin $\mathrm{E}_{2}$-induced $\mathrm{Ca}^{2+}$ influx and affected $\mathrm{Ca}^{2+}$ release from stores, although these changes were not accompanied by a concomitant alteration of the resting calcium level (Kugaya et al., 1997; Tam et al., 1998).

\section{Elevation of basal $\left[\mathrm{Ca}^{2+}\right]_{\mathrm{i}}$ as a central regulatory event in microglial activation}

Could an elevation of the basal $\left[\mathrm{Ca}^{2+}\right]_{\mathrm{i}}$ be causally linked to the reduced ability of activated microglia to respond to an external stimulus with a $\left[\mathrm{Ca}^{2+}\right]_{i}$ transient? We addressed this question in two experimental approaches. First, chelation of the free cytosolic calcium in LPS-activated microglia by intracellular presence of BAPTA did not only bring the $\left[\mathrm{Ca}^{2+}\right]_{\mathrm{i}}$ back to control level but also restored much of the purinoreceptor signaling capacity. Second, the opposite setting, namely an ionophore-imposed rise in $\left[\mathrm{Ca}^{2+}\right]_{\mathrm{i}}$ in naive cultures (no LPS treatment), impaired the ability for receptor-evoked calcium signaling, much in the same way as seen under LPS. In our model, calcium thus serves a "gating" function in the conversion of extracellular stimulations to cytosolic consequences, low basal $\left[\mathrm{Ca}^{2+}\right]_{\mathrm{i}}$ being permissive and increased levels elevating the threshold for a response to build up.

This link between calcium homeostasis and calcium signaling as seen in brain macrophages may even stand for a more general principle. Indeed, such an apparent coincidence was also described in $\mathrm{B}$ and $\mathrm{T}$ lymphocytes. Elevated basal $\left[\mathrm{Ca}^{2+}\right]_{\mathrm{i}}$ as seen in chronically activated B cells correlated with a reduced responsiveness to B cell receptor stimulation (Healy et al., 1997). It was further suggested that the amplitude and duration of $\left[\mathrm{Ca}^{2+}\right]_{i}$ changes determine the differential recruitment of downstream signaling elements in these cells (Dolmetsch et al., 1997). Similarly, elevated basal $\left[\mathrm{Ca}^{2+}\right]_{i}$ was reported in B cells of Igtransgenic mice along with refractory $\mathrm{B}$ cell receptor-mediated calcium mobilization and protein kinase activity (Benschopp et al., 2001). A causal relationship between elevated cytosolic free calcium and a suppressed calcium-mediated signal transduction 
has also been published recently for Jurkat ( $\mathrm{T}$ ) cells (Boldizsar et al., 2002).

Although the increase in basal $\left[\mathrm{Ca}^{2+}\right]_{\mathrm{i}}$ obviously affected the sensory limb of microglial functions as it relies on a receptortriggered calcium signal generation, we also obtained evidence for outcomes on the executive properties of these cells.

\section{Consequences of activation-associated changes in the $\left[\mathrm{Ca}^{2+}\right]_{\mathrm{i}}$ regulation}

Calcium as a second-messenger system influences enzymes, ion channels, and cytoskeletal elements. It also exerts a control on gene transcription (Berridge, 2001). A significant portion of the executive features of activated microglia, i.e., the production of immunoregulatory and neuroregulatory cytokines and chemokines, depends on the de novo synthesis of proteins. We provide evidence for a differential regulation of cytokine-chemokine induction by $\left[\mathrm{Ca}^{2+}\right]_{\mathrm{i}}$. Calcium buffering by BAPTA had an attenuating influence on five studied proteins, the outcome ranging from strong to moderate suppression. Similarly, the production of the diffusible mediator, NO was suppressed under BAPTA. Still, this pattern of individual downregulation indicated that the calcium chelation was not generally affecting the synthesis and release machineries (Fig. 8).

On the contrary, calcium did not dictate cytokine-chemokine induction by itself. Bypassing the LPS receptor system and just lifting $\left[\mathrm{Ca}^{2+}\right]_{\mathrm{i}}$ through an ionophore failed to trigger their release. For cytokines-chemokines, the signaling cascades from the LPS receptor system to their induction thus likely require more than a single route (Marriott et al., 1998; Hanisch et al., 2001). Our data indicate that calcium is not the only control element for the induction of cytokines-chemokines but rather assists in (or facilitates) this process. Ionomycin also failed in driving NO production. Apparently, the activities of NO-synthesizing enzymes are under a similar type of complex control. Calcium is needed for developing full activity but is unable to trigger any synthesis on its own. This assumption is supported by the fact that the "calcium-dependent" (calcium-inducible) version of NO synthases is, indeed, absent in microglia (Agullo et al., 1995).

However, increased basal $\left[\mathrm{Ca}^{2+}\right]_{\mathrm{i}}$ levels per se may not necessarily translate into always the same sensory or functional adjustments. In peritoneal macrophages, an experimental elevation of the resting $\left[\mathrm{Ca}^{2+}\right]_{\mathrm{i}}$ by ionophores did induce NO synthase and thus mimicked LPS (Raddassi et al., 1994). On the contrary, $\left[\mathrm{Ca}^{2+}\right]_{\mathrm{i}}$ elevation in articular chondrocytes led to an almost opposite effect. Ionophores did not trigger NO release but even inhibited an IL-1-induced NO production (Geng and Lotz, 1995).

Decreased ability to translate receptor stimulation into $\left[\mathrm{Ca}^{2+}\right]_{\mathrm{i}}$ transients could represent an intrinsic mechanism of activated cells to shut off sensitivity toward external influences. It could thereby indirectly attenuate additional executive reactions to extracellular signals, as far as they are under the control of $\left[\mathrm{Ca}^{2+}\right]_{\mathrm{i}}$. In addition, downregulation of stimulus-evoked $\left[\mathrm{Ca}^{2+}\right]_{\mathrm{i}}$ increases may serve some protective function because an excessive $\left[\mathrm{Ca}^{2+}\right]_{\mathrm{i}}$ elevation may result in detrimental consequences for microglial cells and their primarily protective action.

\section{References}

abd-el-Basset E, Fedoroff S (1995) Effect of bacterial wall lipopolysaccharide (LPS) on morphology, motility, and cytoskeletal organization of microglia in cultures. J Neurosci Res 41:222-237.

Agullo L, Baltrons MA, Garcia A (1995) Calcium-dependent nitric oxide formation in glial cells. Brain Res 686:160-168.

Bambrick LL, Golovina VA, Blaustein MP, Yarowsky PJ, Krueger BK (1997)
Abnormal calcium homeostasis in astrocytes from the trisomy 16 mouse. Glia 19:352-358.

Benschop RJ, Aviszus K, Zhang X, Manser T, Cambier JC, Wysocki LJ (2001) Activation an anergy in bone marrow B cells of a novel immunoglobulin transgenic mouse that is both hapten specific and autoreactive. Immunity 14:33-43.

Berridge MJ (2001) The versatility and complexity of calcium signalling. Novartis Found Symp 239:52-64.

Boddeke EW, Meigel I, Frentzel S, Gourmala NG, Harrison JK, Buttini M, Spleiss O, Gebicke-Harter P (1999) Cultured rat microglia express functional beta-chemokine receptors. J Neuroimmunol 98:176-184.

Boldizsar F, Berki T, Miseta A, Nemeth P (2002) Effect of hyperglycemia on the basal cytosolic free calcium level, calcium signal and tyrosinephosphorylation in human T cells. Immunol Lett 82:159-164.

Dolmetsch M, Lewis RS, Goodnow CC, Healy JI (1997) Differential activation of transcription factors induced by $\mathrm{Ca}^{2+}$ response amplitude and duration. Nature 386:855-858.

Gasque P, Singhrao SK, Neal JW, Gotze O, Morgan BP (1997) Expression of the receptor for complement $\mathrm{C} 5 \mathrm{a}(\mathrm{CD} 88)$ is up-regulated on reactive astrocytes, microglia, and endothelial cells in the inflamed human central nervous system. Am J Pathol 150:31-41.

Geng Y, Lotz M (1995) Increased intracellular $\mathrm{Ca}^{2+}$ selectively suppresses IL-1-induced NO production by reducing iNOS mRNA stability. J Cell Biol 129:1651-1657.

Grynkiewicz G, Poenie M, Tsien RY (1985) A new generation of $\mathrm{Ca}^{2+}$ indicators with greatly improved fluorescence properties. J Biol Chem 260:3440-3450.

Guha M, Mackman N (2001) LPS induction of gene expression in human monocytes. Cell Signal 13:85-94.

Hanisch UK (2001) Microglia as a source and target of cytokine activities in the brain. In: Microglia in the degenerating and regenerating CNS (Streit WJ, ed), pp 79-124. New York: Springer.

Hanisch UK (2002) Microlgia as a source and target of cytokines. Glia 40:140-155.

Hanisch UK, Prinz M, Angstwurm K, Hausler KG, Kann O, Kettenmann H, Weber JR (2001) The protein tyrosine kinase inhibitor AG126 prevents the massive microglial cytokine induction by pneumococcal cell walls. Eur J Immunol 31:2104-2115.

Harrison JK, Jiang Y, Chen S, Xia Y, Maciejewski D, McNamara RK, Streit WJ, Salafranca MN, Adhikari S, Thompson DA, Botti P, Bacon KB, Feng L (1998) Role for neuronally derived fractalkine in mediating interactions between neurons and CX3CR1-expressing microglia. Proc Natl Acad Sci USA 95:10896-10901.

Häusler KG, Prinz M, Nolte C, Weber JR, Schumann RR, Kettenmann H, Hanisch UK (2002) Interferon-gamma differentially modulates the release of cytokines and chemokines in lipopolysaccharide- and pneumococcal cell wall-stimulated mouse microglia and macrophages. Eur J Neurosci 16:2113-2122.

Healy JI, Dometsch RE, Timmerman LA, Cyster JG, Thomas ML, Crabtree GR, Lewis RS, Goodnow CC (1997) Different nuclear signals are activated by the $\mathrm{B}$ cell receptor during positive versus negative signaling. Immunity 6:419-428.

Hide I, Tanaka M, Inoue A, Nakajima K, Kohsaka S, Inoue K, Nakata Y (2000) Extracellular ATP triggers tumor necrosis factor-alpha release from rat microglia. J Neurochem 75:965-972.

Hopkins SJ, Rothwell NJ (1995) Cytokines and the nervous system. I. Expression and recognition. Trends Neurosci 18:83-88.

Kirschning CJ, Wesche H, Merrill AT, Rothe M (1998) Human toll-like receptor 2 confers responsiveness to bacterial lipopolysaccharide. J Exp Med 188:2091-2097.

Kreutzberg GW (1996) Microglia: a sensor for pathological events in the CNS. Trends Neurosci 19:312-318.

Kugaya A, Kagaya A, Zensho H, Oyamada T, Tawara Y, Inagaki M, Uchitomi Y, Yamawaki S (1997) Modulation of endothelin-induced intracellular $\mathrm{Ca}^{2+}$ mobilization by interleukin-1 beta and lipopolysaccharide in C6 rat glioma cells. Neuropeptides 31:187-192.

Lowry MA, Goldberg JI, Belosevic M (1999) Treatment of the macrophagelike P388D.1 cells with bacterial lipopolysaccharide and interferongamma causes long-term alterations in calcium metabolism. Dev Comp Immunol 23:253-261.

Marriott I, Bost KL, Mason MJ (1998) Differential kinetics for induction of interleukin-6 mRNA expression in murine peritoneal macrophages: evi- 
dence for calcium-dependent and independent signalling pathways. J Cell Physiol 177:232-240.

Martinez MC, Muller B, Stoclet JC, Andriantsitohaina R (1996) Alteration by lipopolysaccharide of the relationship between intracellular calcium levels and contraction in rat mesenteric artery. $\mathrm{Br} \mathrm{J}$ Pharmacol 118:1218-1222.

Mattson MP, Cheng B, Davis D, Bryant K, Lieberburg I, Rydel RE (1992) $\beta$-Amyloid peptides destabilize calcium homeostasis and render human cortical neurons vulnerable to excitotoxicity. J Neurosci 12:376-389.

Merrill JE, Benveniste EN (1996) Cytokines in inflammatory brain lesions: helpful and harmful. Trends Neurosci 19:331-338.

Möller T, Nolte C, Burger R, Verkhratsky A, Kettenmann H (1997) Mechanisms of $\mathrm{C} 5 \mathrm{a}$ and $\mathrm{C} 3 \mathrm{a}$ complement fragment-induced $\left[\mathrm{Ca}^{2+}\right]$ i signaling in mouse microglia. J Neurosci 17:615-624.

Möller T, Hanisch UK, Ransom BR (2000a) Thrombin-induced activation of cultured rodent microglia. J Neurochem 75:1539-1547.

Möller T, Kann O, Verkhratsky A, Kettenmann H (2000b) Activation of mouse microglial cells affects P2 receptor signaling. Brain Res 853:49-59.

Nataf S, Stahel PF, Davoust N, Barnum SR (1999) Complement anaphylatoxin receptors on neurons: new tricks for old receptors? Trends Neurosci 22:397-402.

Noda M, Nakanishi H, Nabekura J, Akaike N (2000) AMPA-kainate subtypes of glutamate receptor in rat cerebral microglia. J Neurosci 20:251-258.

Nolte C, Moller T, Walter T, Kettenmann H (1996) Complement 5a controls motility of murine microglial cells in vitro via activation of an inhibitory G-protein and the rearrangement of the actin cytoskeleton. Neuroscience 73:1091-1107.

Nörenberg W, Gebicke-Haerter PJ, Illes P (1994) Voltage-dependent potassium channels in activated rat microglia. J Physiol (Lond) 475:15-32.

Prinz M, Kann O, Draheim HJ, Schumann RR, Kettenmann H, Weber JR, Hanisch UK (1999) Microglial activation by components of Grampositive and -negative bacteria: distinct and common routes to the induction of ion channels and cytokines. J Neuropathol Exp Neurol 58:1078-1089.

Prinz M, Häusler KG, Kettenmann H, Hanisch UK (2001) $\beta$-adrenergic receptor stimulation selectively inhibits IL-12p40 release in microglia. Brain Res 899:264-270.

Raddassi K, Berthon B, Petit JF, Lemaire G (1994) Role of calcium in the activation of mouse peritoneal macrophages: induction of NO synthase by calcium ionophores and thapsigargin. Cell Immunol 153:443-455.
Raivich G, Haas S, Werner A, Klein MA, Kloss C, Kreutzberg GW (1998) Regulation of MCSF receptors on microglia in the normal and injured mouse central nervous system: a quantitative immunofluorescence study using confocal laser microscopy. J Comp Neurol 395:342-358.

Raivich G, Bohatschek M, Kloss CU, Werner A, Jones LL, Kreutzberg GW (1999a) Neuroglial activation repertoire in the injured brain: graded response, molecular mechanisms and cues to physiological function. Brain Res Brain Res Rev 30:77-105.

Raivich G, Jones LL, Werner A, Bluthmann H, Doetschmann T, Kreutzberg GW (1999b) Molecular signals for glial activation: pro- and antiinflammatory cytokines in the injured brain. Acta Neurochir Suppl (Wien) 73:21-30.

Ralevic V, Burnstock G (1998) Receptors for purines and pyrimidines. Pharmacol Rev 50:413-492.

Schumann RR, Leong SR, Flaggs GW, Gray PW, Wright SD, Mathison JC, Tobias PS, Ulevitch RJ (1990) Structure and function of lipopolysaccharide binding protein. Science 249:1429-1431.

Schwaiger FW, Hager G, Raivich G, Kreutzberg GW (1998) Cellular activation in neuroregeneration. Prog Brain Res 117:197-210.

Streit WJ, Walter SA, Pennel NA (2000) Reactive microgliosis. Prog Neurobiol 57:563-581.

Tam VK, Schotland S, Green J (1998) Inflammatory cytokines (IL-1alpha, TNF-alpha) and LPS modulate the $\mathrm{Ca}^{2+}$ signaling pathway in osteoblasts. Am J Physiol 274:C1686-C1698.

Tawara Y, Kagaya A, Uchitomi Y, Horiguchi J, Yamawaki S (1998) Lipopolysaccharide regulates both serotonin- and thrombin-induced intracellular calcium mobilization in rat C6 glioma cells: possible involvement of nitric oxide synthase-mediated pathway. J Neurosci Res 51:517-525.

Toescu EC, Moller T, Kettenmann H, Verkhratsky A (1998) Long-term activation of capacitative $\mathrm{Ca}^{2+}$ entry in mouse microglial cells. Neuroscience 86:925-935.

Ulevitch RJ, Tobias PS (1995) Receptor-dependent mechanisms of cell stimulation by bacterial endotoxin. Annu Rev Immunol 13:437-457.

Van Beek J, Bernaudin M, Petit E, Gasque P, Nouvelot A, MacKenzie ET, Fontaine M (2000) Expression of receptors for complement anaphylatoxins C3a and C5a following permanent focal cerebral ischemia in the mouse. Exp Neurol 161:373-382.

Verkhratsky A, Kettenmann H (1996) Calcium signalling in glial cells. Trends Neurosci 19:346-352.

Verkhratsky A, Orkand RK, Kettenmann H (1998) Glial calcium: homeostasis and signaling function. Physiol Rev 78:99-141. 